\title{
RELATIONSHIP BETWEEN PARAOXONASE-1 ACTIVITY AND LIPID MOBILISATION IN PERIPARTURIENT SAANEN GOATS
}

\author{
AKGUL, G. ${ }^{1}$, MECITOGLU, Z. ${ }^{2}$, OZEN, D. ${ }^{3}$, KUCUKSEN, D.U. ${ }^{4}$, \\ AKGUL, M.B. ${ }^{5}$ and SENTURK, S. ${ }^{2}$
}

\footnotetext{
${ }^{1}$ Department of Internal Medicine, Faculty of Veterinary Medicine, Siirt University, Siirt, Turkey. ${ }^{2}$ Department of Internal Medicine, Faculty of Veterinary Medicine, Uludag University, Bursa, Turkey. ${ }^{3}$ Department of Biostatistics, Faculty of Veterinary Medicine, Ankara University, Ankara, Turkey.

${ }^{4}$ Department of Biochemistry, Faculty of Veterinary Medicine, Siirt University, Siirt, Turkey

${ }^{5}$ Department of Surgery, Faculty of Veterinary Medicine, Siirt University, Siirt, Turkey.
}

Received: 10 December 2018; Accepted: 22 December 2018

\begin{abstract}
Saanen goat is one of the highest milk-producing goat breeds and is greater than the other breeds of goats, has a high reproductive yield. The aim of this study was to investigate the relationship between paraoxonase-1 (PON1) activity and lipid mobilisation in periparturient period of Saanen dairy goats. Fifteen Saanen goats (aged 2-3) were selected for the study. Blood samples were collected from each goat on days $-21,-14,-7,0,7,14$ and 21 relative to parturition. Blood non-esterified fatty acids (NEFA), $\beta$-hydroxybutyric acid (BHBA), triglycerides (TG), total cholesterol (CHOL), Low-density lipoprotein (LDL), high-density lipoprotein (HDL) and very lowdensity lipoprotein (VLDL) and Paraoxonase-1 activity (PON1) levels were measured. Triglyceride concentrations decreased significantly $(\mathrm{P}<0.001)$ from parturition until day 21 as compare to the values obtained before parturition. Serum HDL concentrations were significantly lower values on days $-21,-14$ and $-7(\mathrm{P}<0.001)$ compared to values on days 14 and 7. Serum VLDL concentrations increased significantly from parturition until day prepartum 21 as compare to the values obtained before parturition $(\mathrm{P}<0.001)$. Serum LDL levels were significantly higher on day -21 and -14 compared to values on days +7 and $+14(\mathrm{P}<0.001)$. Serum BHBA levels significantly higher on days -21 compared to values on days $-14,-7,+7$ and $+14(\mathrm{P}<0.001)$. Serum NEFA levels significantly lower on days -21 compared on days -14 and parturition. PON-1 and CHOL levels were no statistical difference. In conclusion, although there was no statistical differences, significant changes in levels of PON-1 were occurred in periparturient Saanen goats and PON-1 may be used as biomarker for metabolic and inflammatory-related and or disorders in periparturient goats. Further study should be conducted for better understanding the determine the availability of PON-1 as a marker of oxidative stress and to confirm these findings.
\end{abstract}

Key words: Goat, Lipid Mobilisation, Non-esterified fatty acids, Paraoxonase-1 activity.

\section{INTRODUCTION}

Saanen goat is one of the highest milkproducing goat breeds and is greater than the other breeds of goats, has a high reproductive yield. It is well adapted to different conditions (Temizel et al., 2009, Pesmen and Yardimci, 2008).

The periparturient period from late pregnancy to early lactation in dairy goats is a critical period associated with physiological and metabolic

Corresponding author: Gülşah Akgül,

E-mail address: gulsahvet@ hotmail.com

Present address: Department of Internal Medicine, Faculty of Veterinary Medicine, Siirt University, Siirt, Turkey. adaptations to support foetal growth and milk production (Goff and Horst, 1997). Metabolic disorders usually develop during this period when goats undergo significant hormonal, metabolic, and nutritional processes and prepare for the lactation that follows the parturition, (Senturk et al., 2010, Demir et al., 2012) Lipid profiles have been used to diagnose metabolic diseases and the assessment of the nutritional status of animals (Bickerstaffe, 1971).

The periparturient period is characterized by elevation of circulating ketone bodies and negative energy balance (NEB). During early lactation, goats mobilize body fat reserves from adipose tissue, resulting in increased concentrations of nonesterified fatty acids (NEFA) in the blood. The 
majority of NEFA are metabolized in the liver into acetyl-coA and consequently into ketone bodies, such as $\beta$-hydroxybutirate (BHBA) (Drackley et al., 2001) Both NEFA and BHBA are considered as good markers of excessive NEB and lipomobilisation syndrome (Chapınal et al., 2011). The intensified process of NEFA oxidation in the liver results in increased production of reactive oxygen species (ROS) and oxidative stress during the periparturient period (Mudron et al., 1999, Turk et al., 2013). PON1 plays an important physiological role in lipid metabolism by hydrolysis of oxidized lipids, in the form of lipid hydroperoxides, generated on lipoproteins such as High-density lipoprotein (HDL) and Low-density lipoprotein (LDL) and within this ability it is considered as an antioxidative/anti-inflammatory component of HDL. Thus it provides protection against the development of oxidative stress, though the exact mechanism by which PON1 reverse and prevent liver damage by exogenous antioxidants PON1 enzyme protects LDL, bad cholesterol, from oxidation and neutralizes radicals including hydrogen peroxide by its antioxidant property (Arslan et al., 2012).

The aim of this study was to investigate the relationship between Paraoxonase-1 Activity and lipid mobilisation in healthy goats in different stages of the reproductive and lactation cycle.

\section{MATERIALS AND METHOS}

\section{Animals and sample collection}

Saanen goats $(n=15)$ with an expected parturition date within the next 7 days were selected for the study. All goats were from the same herd and yield group, and the management and feeding conditions were identical for all animals. The mean milk production during the last lactation was $750-1000 \mathrm{~kg}$ (270 days) per goats. Puerperium was physiological in all animals. Blood samples were taken by puncturing vena jugularis three, two and one weeks before parturition, on the parturition day, and 7, 14 and 21 days after parturition. Animals which parturition more than 2 days earlier or later were not included in the study. According to Eicher et al. (1998) blood BHBA levels increase after feeding thus it is suggested to collect blood samples $4-5 \mathrm{~h}$ after feeding in order to determine peak concentration of BHBA. After the samples were precipitated, they were centrifuged at 3000 r.p.m. 5 min. The serum obtained was frozen at $-20{ }^{\circ} \mathrm{C}$ until examined. Samples for NEFA analysis were collected before morning feeding.

\section{Biochemical analyses}

Serum total cholesterol (CHOL), triglycerides (TG), high-density lipoprotein (HDL), low-density lipoprotein (LDL), very low density lipoprotein (VLDL) were measured using autoanalyzer. Nonesterified fatty acids (NEFA) ( Goat NEFA ELISA kit), $\beta$-hydroxybutirate (BHBA) (Goat BHBA ELISA kit) and Paraoxonase-1 (PON 1) (Goat Paraoxonase assay fully automated kit) were measured using ELISA.

\section{Statistical analysis:}

Descriptive statistics for each variable were calculated. For all outcome measures, a within subjects repeated measures of analysis of variance was performed to determine the significant change over time. Sphericity assumptions was checked using Mauchly's test. In cases when the sphericity based on Mauchly's sphericity criterion had been violated, the probabilities for the time hypotheses were adjusted by reducing the degrees of freedom according to the Greenhouse-Geiser procedure. Bonferroni test for multiple comparison and polynomial contrasts for trend analysis were used as post hoc procedure. SPSS 14.01 package program was used for statistical analysis. $\mathrm{P}<0.05$ was used in all statistical evaluations.

\section{RESULT}

Triglyceride concentrations decreased significantly $(\mathrm{P}<0.001)$ from parturition until day 21 as compare to the values obtained before parturition (Figure 1). Serum HDL concentrations were significantly lower values on days $-21,-14$ and $-7(\mathrm{P}<0.001)$ compare to values on days 14 and 7 . Serum VLDL concentrations increased significantly from parturition until day prepartum 21 as compare to the values obtained before parturition $(\mathrm{P}<0.001)$ (Figure 1). Serum LDL levels were significantly higher on day -21 and -14 compare to values on days +7 and $+14(\mathrm{P}<0.001)$. Serum BHBA levels significantly higher on days -21 compare to values on days -14 , $7,+7$ and $+14 \quad(\mathrm{P}<0.001)$. And BHBA levels significantly lower on days -14 compare to values on days +21. (Figure 1) Serum NEFA levels significantly lower on days -21 compare on days -14 and parturition. NEFA levels similar significantly higher on parturition compare to values on days -14 , and parturition significantly higher compare on days +7 and $+14(\mathrm{P}<0.001)$ (Figure 1). PON-1 and CHOL levels were no no statistical difference. All results were presented in Table 1. 
Table 1: Mean values ( \pm SEM) of metabolic parameters, lipid metabolism and PON1 activity in Saanen goats during the preparturient period.

\begin{tabular}{ccccccccc} 
Weeks & PON-1 & CHOL & TG & VLDL & LDL & HDL & BHBA & NEFA \\
\hline $\mathbf{- 2 1}$ & $90,14 \pm 13,95$ & $94 \pm 3,63$ & $32,6 \pm 3,42^{\mathrm{a}}$ & $6,52 \pm 0,68^{\mathrm{a}}$ & $32,53 \pm 2,55^{\mathrm{ab}}$ & $51,8 \pm 2,4^{\mathrm{ab}}$ & $0,45 \pm 0,05^{\mathrm{ac}}$ & $0,33 \pm 0,05^{\mathrm{b}}$ \\
$\mathbf{- 1 4}$ & $86,62 \pm 15,61$ & $91 \pm 3,78$ & $33,8 \pm 3,29^{\mathrm{a}}$ & $6,76 \pm 0,66^{\mathrm{a}}$ & $33,8 \pm 2,94^{\mathrm{ab}}$ & $52,6 \pm 2,06^{\mathrm{ab}}$ & $0,17 \pm 0,03^{\mathrm{b}}$ & $0,19 \pm 0,02^{\mathrm{c}}$ \\
$\mathbf{- 7}$ & $91,82 \pm 15,15$ & $88,27 \pm 3,06$ & $40,6 \pm 3,94^{\mathrm{a}}$ & $8,12 \pm 0,79^{\mathrm{a}}$ & $29,13 \pm 2,23^{\mathrm{abc}}$ & $50,53 \pm 1,42^{\mathrm{a}}$ & $0,15 \pm 0,04^{\mathrm{b}}$ & $0,29 \pm 0,06^{\mathrm{bc}}$ \\
$\mathbf{0}$ & $106 \pm 17,18$ & $82,53 \pm 3,02$ & $9,67 \pm 0,65^{\mathrm{b}}$ & $1,93 \pm 0,13^{\mathrm{b}}$ & $22,27 \pm 1,55^{\mathrm{ac}}$ & $53,93 \pm 2,7^{\mathrm{abc}}$ & $0,4 \pm 0,07^{\mathrm{abc}}$ & $0,59 \pm 0,07^{\mathrm{a}}$ \\
$\mathbf{7}$ & $100,95 \pm 17,75$ & $89,6 \pm 3,11$ & $14,93 \pm 1,35^{\mathrm{c}}$ & $2,99 \pm 0,27^{\mathrm{c}}$ & $30,47 \pm 1,71^{\mathrm{b}}$ & $56,4 \pm 1,7^{\mathrm{abc}}$ & $0,18 \pm 0,03^{\mathrm{b}}$ & $0,29 \pm 0,05^{\mathrm{bc}}$ \\
$\mathbf{1 4}$ & $97,59 \pm 14,59$ & $88,27 \pm 3,86$ & $12,67 \pm 1,02^{\mathrm{bc}}$ & $2,53 \pm 0,2^{\mathrm{bc}}$ & $24,6 \pm 1,75^{\mathrm{c}}$ & $58,2 \pm 2,5^{\mathrm{bc}}$ & $0,27 \pm 0,05^{\mathrm{ab}}$ & $0,27 \pm 0,07^{\mathrm{bc}}$ \\
$\mathbf{2 1}$ & $103,74 \pm 17,46$ & $92,07 \pm 3,84$ & $14,8 \pm 1,08^{\mathrm{c}}$ & $2,96 \pm 0,22^{\mathrm{c}}$ & $27,27 \pm 1,55^{\mathrm{abc}}$ & $63,47 \pm 2,59^{\mathrm{c}}$ & $0,61 \pm 0,07^{\mathrm{c}}$ & $0,17 \pm 0,03^{\mathrm{abc}}$ \\
P-value & $\mathbf{0 , 5 1 3}$ & $\mathbf{0 , 0 9 4}$ & $<\mathbf{0 , 0 0 1}$ & $<\mathbf{0 , 0 0 1}$ & $<\mathbf{0 , 0 0 1}$ & $<\mathbf{0 , 0 0 1}$ & $<\mathbf{0 , 0 0 1}$ & $<\mathbf{0 , 0 0 1}$ \\
(Time) & $\mathbf{0 , 3 7 2}$ & $\mathbf{0 , 5 4 7}$ & $<\mathbf{0 , 0 0 1}$ & $<\mathbf{0 , 0 0 1}$ & $\mathbf{0 , 0 0 3}$ & $\mathbf{0 , 0 0 1}$ & $\mathbf{0 , 0 4 9}$ & $\mathbf{0 , 4 7}$ \\
Linear & $\mathbf{0 , 5 4 6}$ & $\mathbf{0 , 0 5 1}$ & $\mathbf{0 , 1 0 9}$ & $\mathbf{0 , 1 0 8}$ & $\mathbf{0 , 0 6}$ & $\mathbf{0 , 0 1 4}$ & $<\mathbf{0 , 0 0 1}$ & $<\mathbf{0 , 0 0 1}$ \\
Quadratic & $\mathbf{0 , 6 7 3}$ & $\mathbf{0 , 9 1 6}$ & $<\mathbf{0 , 0 0 1}$ & $<\mathbf{0 , 0 0 1}$ & $\mathbf{0 , 2 7 1}$ & $\mathbf{0 , 9 3 6}$ & $\mathbf{0 , 8 1 4}$ & $\mathbf{0 , 0 6 5}$ \\
Cubic & $\mathbf{0 , 0 0 1}$ & &
\end{tabular}

* $\mathrm{P}<0.001 ;$, a,b,c,: The different superscript letters in the same column indicate significant difference statistically $(\mathrm{p}<0.001)$

(-21; Preparum 21, -14; Prepartum 14, -7; Preparum 7, 0: Parturition, +7; Postpartum 7, +14; Postpartum 14, +21; Postpartum 21)

Figure 1:

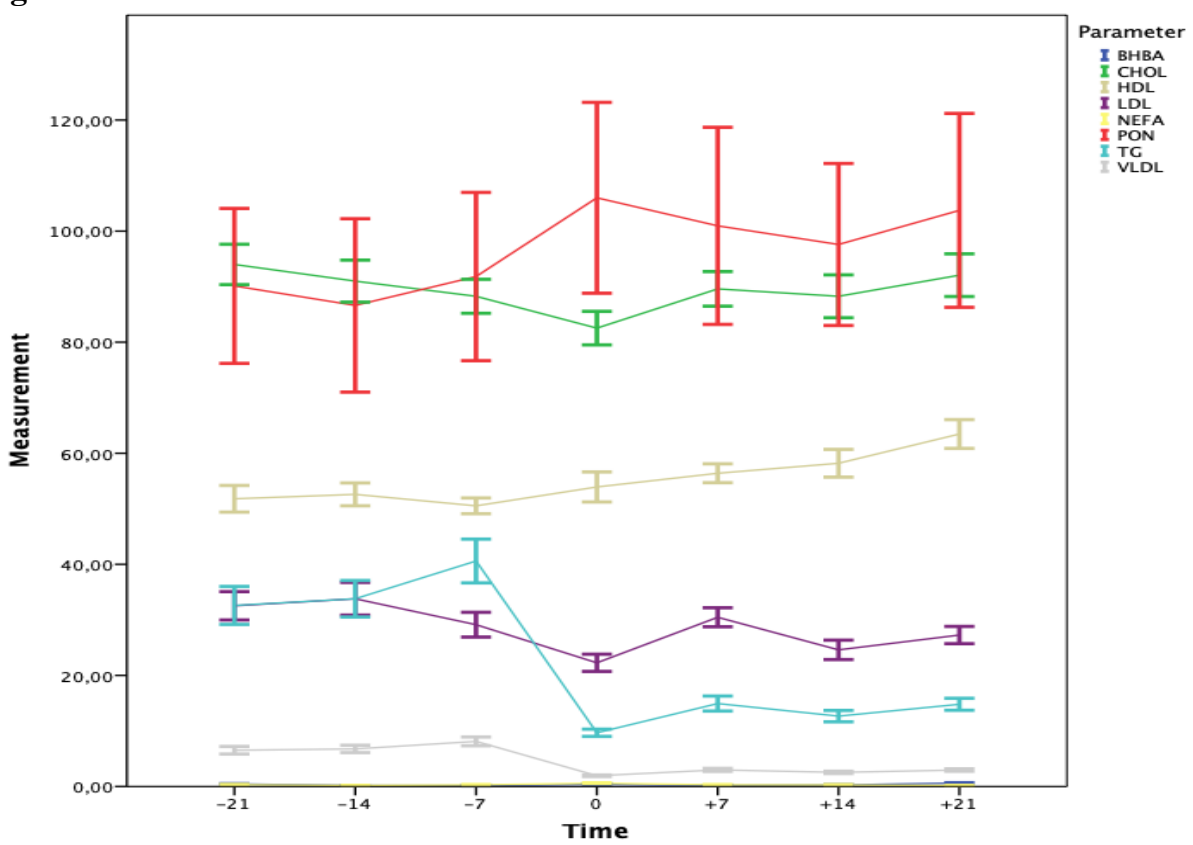

\section{DISCUSSION}

The present study demonstrated the changes in lipid metabolism and PON1 activity during the preparturient period in Saanen goats. Requirements for glucose and metabolizable energy increase two- to threefold from $21 \mathrm{~d}$ before to $21 \mathrm{~d}$ after parturition. The liver must adapt quickly to provide the increased glucose needed to support high milk production, and to process the flood of nonesterified fatty acids taken up from extensive mobilization of adipose triglycerides. 
The Maximum levels of TG on day 7 prepartum was detected (Figure 1) Triglyceride concentrations significantly declined at parturition and remained at lower values until day 21 of lactation. Changes in this factor were inconsistent in the lactation period. Decreased triglyceride concentration in the weeks of gestation are similar to those in cows (Seifi et al., 2007). As highlighted in the data on cattle, higher eserum triglyceride concentrations in the prepartum period may be due to lower matabolism due toy he lactating stage ( Marcos et al., 1990) or due ton o triglyceride uptake by mamary gland form ilk fat synthesis (Grummer, 1993).

Serum CHOL levels were decreased at parturition, although with no statistical difference (Table 1). Studies in sheep reported that cholesterol and triglyceride concentrations were higher compared to non-pregnant sheep Hamadeh et al. (1996) and AlDewachi (1999) explained that, this increase during the last weeks of pregnancy in sheep appears to be related to the energy demands of the foetal-placental unit in pregnant ewes (Watson et al., 1993) but it does not match present work. Both VLDL, LDL and HDL (Figure 1) decreased at parturition, with an increase during lactation. These lipid changes are typical during the transition period in cows, as was previously reported Grummer, (1993) and Turk et al. (2008)

High-density lipoproteins (HDLs) have long been known to be antiatherogenic (D.J. Gordon, B.M. Rifkind 1989) and their protective role has been attributed to partially associated enzymes (Navab et al., 1996) of these, paraoxonase 1 (PON1) - an esterase synthesized and stored mainly by liver and a broad substrate specificity (Primo-Parmo et al., 1996) PON1 limits the accumulation of lipid oxidation products in low-density lipoproteins (LDL) and HDL (Aviram et al., 1998).

In present study, although there was no statistical difference, serum PON1 activity increased at parturition and decreased on prepartum (Figure 1). Oxidative stress is considered a remarkable component in the relevant signaling processes, inflammatory responses including stimulation of cell adhesion molecules and production chemoattractant. High-density lipoprotein plays an important role as anti-oxidative / anti-inflammatory. The particle provides non-specific defense of a host. This action of HDL various structural proteins and enzymes carried on the particle including PON1. (Link et al., 2007, Turk, 2009). In addition, Feingold et al., 1998) reported decreased PON1 mRNA expression in liver and decreased serum PON1 activity in rodents threatened by cytokines mediating APR, PON1 may show acute acute response to inflammatory conditions phase protein (APP). Thus, lower PON1 and increased oxidative stress mechanism by which NEB mediates inflammatory responses, and increases the incidence of reproduction and production diseases in the onset of lactation. Previous studies in periparturient dairy cows have observed decreased PON1 activity ,suggesting inflammatory conditions around parturition (B1onaz et al., 2007, Bossaert et al., 2012). In present study, although the highest day was on parturition, Salar et al. (2018) were reported that serum PON-1 levels were minimum on parturition day.

In presented study, NEFA concentrations in the serum of Saanen is peak level on the day of parturition (Figure 1). After parturition, changes in NEFA concentrations gradually decreased until 21 days postpartum. Changes in NEFA concentrations reflect the fat mobilization rate from fat stores due to NEB. The gradual increase in plasma NEFA in the final days of pregnancy can be explained by the gradual depression of DMI observed during this time (Sadjadian et al., 2013, Bertics et al. 1992). The high NEFA concentration around calving time is consistent with the results obtained in cows and sheep (Busato et al., 2002, Seifi et al., 2007). NEFA reached a peak level and then decreased in the first weeks of lactation; this is similar to results presented by Vazquez-Annon et al. (1994).

It can be monitored and tested for NEB, BHBA or NEFA in dairy products. cattle. NEB is a threshold condition and the goats are only affected when BHBA and / or NEFA concentrations increase. BHBA is one of the important energy status indicators during the periparturient period (Sadjadian et al., 2013). According to the results of our study, BHBA concentrations are peak level on the 21 day of postpartum (Figure 1). It is smiliar others study which was a consequence of increased NEFA around parturition (Vanholder et al., 2005, Bionaz et al., 2007, Turk et al., 2013). Blood concentrations of BHBA of 0.8 to $1.6 \mathrm{mmol} / \mathrm{L}$ are determinate of a NEB in ewes (Navarre and Pugh, 2002). In presented study, there was no values for NEB.

\section{CONCLUSION}

In conclusion, in the present study, indicating the relationship of PON1 with lipid metabolism as well as the involvement of PON1 in immune-related disorders in periparturient goats. Although there was no statistical differences, significant changes in levels of PON-1 occurred in periparturient Saanen goats and PON-1 may be used as biomarker for metabolic and inflammatory-related disorders in periparturient goats. Further study should be conducted for better understanding the determine the 
availability of PON-1 as a marker of oxidative stress and to confirm these findings.

\section{REFERENCES}

Al-Dewachi, O.S. (1999): Some biochemical constituents in the blood serum of pregnant Awassi ewes. Iraqi J Vet. Sci., 12, 275-279.

Arslan, M.; Gencer, N.; Arslan, O. and Guler, O.O. (2012): In vitro efficacy of some cattle drugs on bovine serum paraoxonase 1 (PON1) activity. J Enzyme Inhib Med Chem, 27, 722729.

Aviram, M.; Rosenblat, M.; Bisgaier, C.L.; Newton, R.S.; Primo-Parmo, S.L. and La Du, B.N. (1998): Paraoxonase inhibits high-density lipoprotein oxidation and preserves its functions. A possible peroxidative role for paraoxonase. J Clin Invest,101, 1581-1590.

Bertics, J.S.; Grummer, R.R.; Cadorniga-Valino, C. and Stoddard, E.E. (1992): Effect of prepartum dry matter intake on liver triglyceride concentration and early lactation. J Dairy Sci, 75,1914-1922.

Bıonaz, M.; Trevisı, E.; Calamarl, L.; Lıbrandı, F.; Ferrarı, A. and Bertonı, G. (2007): Plasma paraoxonase, health, inflammatory conditions, and liver function in transition dairy cows. J. Dairy Sci, 90, 1740-1750.

Bossaert, P.; Trevisl, E.; Opsomer, G.; Bertonı, G.; De Vliegher, S, and Leroy, J.L. (2012): The association between indicators of inflammation and liver variables during the transition period in high-yielding dairy cows: an observational study. Vet J, 192, 222-225.

Busato, A.; Faissler, D.; Kupfer, U. and Blum, J.W. (2002): Body condition scores in dairy cows: association with metabolic and endocrine changes in healthy dairy cows. J. Vet. Med. Ser A, 49, 455-460.

Chapınal, N.; Carson, M.; Duffield, T.F.; Capel, M.; Godden, S.; Overton, M.W.; Santos, J.E.P. and Leblanc, SJ. (2011): The association of serum metabolites with clinical disease during the transition period. J. Dairy Sci, 94, 4897-4903.

Demir, G.; Mecitoğlu, Z.; Çatık, S. and Şentürk, S. (2012): Comparison Of Two Cow Side BHBA Test For Diagnosis Of Subclinical Ketosis. Uludag Univ J. Fac. Vet. Med., 31, 7-10.

Drackley, J.K.; Overton, T.R and Doulas, G. (2001): Adaptations of glucose and longchain fatty acid metabolism in liver of dairy cows during the periparturient period. J. Dairy Sci, 84,100-112.

Eicher, R.; Liesegang, A.; Bouchard, E. and Tremblay, A. (1998): Influence of concentrate feeding frequency and intrinsic factors on diurnal variations of blood metabolites in dairy cows. Proc Am Assoc Bov Pract Rome,198-202.

Felngold, K.R.; Memon, R.A.; Moser, A.H and Grunfeld, C. (1998): Paraoxonase activity in the serum and hepatic mRNA levels decrease during the acute phase response. Atherosclerosis, 139, 307-315.

Goff, J.P. and Horst, R.L. (1997): Physiological changes at parturition and their relationship to metabolic disorders. J. Dairy Sci, 80, 12601268.

Gordon, D.J. and Rifkind, S.M. (1989): High-density lipoprotein - the clinical implications of recent studies. N Engl J Med, 321, 13111316.

Grummer, R.R. (1993): Etiology of lipid-related metabolic disorders in periparturient dairy cows. J Dairy Sci, 76, 3882-3896.

Hamadeh, M.E.; Bostedt, $H$ and Failing, K. (1996): Concentration of metabolic parameters in the blood of heavily pregnant and nonpregnant ewes. Berl Und Munchener Tierarztliche Wochenschr, 109, 81-86.

Lınk, J.J.; Rohatgl, A and De Lemos, J.A. (2007): HDL cholesterol: physiology, pathophysiology and management. Curr Probl Cardiol, 32, 268-314.

Marcos, E.; Mazur, A.; Cardot, P. and Rayssigvier, Y. (1990): Serum apolipoprotein B and A-1 and naturally occurring fatty liver in dairy cows. Lipids, 25, 575.

Mudron, P.; Rehage, J.; Qualmann, K.; Sallman, H.P. and Scholz, H. (1999): A study of lipid peroxidation and vitamin $\mathrm{E}$ in dairy cows with hepatic insufficiency. J.Vet. Med. A, 46, 219-224.

Navab, M.; Berliner, J.A.; Watson, A.D.; Hama, S.Y.; Territo, M.C.; Lusis, A.J. and Edwards, P.A. (1996): The yin and yang of oxidation in the development of the fatty streak. A review based on the 1994 George Lyman Duff Memorial Lecture. Arterioscler Thromb Vasc Biol, 16, 831-842.

Pesmen, G. and Yardimci, M. (2008): Estimating the live weight using somebody measurements in Saanen goats. Arch Zootech, 11, 30-40.

Primo-Parmo, S.L.; Sorenson, R.C.; Teiber, J and La Du, B.N. (1996): The human serum paraoxonase/ arylesterase gene (PON1) is one member of a multigene family Genomics, 33, 498-507.

Sadjadian, R.; Seifi, H.A.; Mohri, M.; Naserian, A.A. and Farzaneh, N. (2013): Variations of energy biochemical metabolites in periparturient dairy Saanen goats. Comp Clin Path, 22, 449-456.

Salar, S.; Baştan, I.; Baştan, A.; Pekcan, M. and Tevhide, S.E.L. (2018): Investigation of Changes in Metabolic Parameters and Paraoxonase-1 During the Transition Period 
in Turkish Saanen Goats. Kafkas Üniversitesi Veteriner Fakültesi Dergisi, 24.

Seifi, H.A.; Gorji-Dooz, M.; Mohri, M.; Dalirnaghadeh, B. and Farzaneh, N. (2007): Variations of energy-related biochemical metabolites during transition period in dairy cows. Comp Clin Path, 16, 253-58.

Senturk, S.; Mecitoglu, Z.; Temizel, E.M.; Cihan, H.; Kasap, S. and Demir, G. (2010): Clinical and biochemical evaluation of cows occuring severe weight loss after calving. Uludag Univ J Fac Vet Med, 29, 43-49.

Turk, R.; Juretıć, D.; Gereš, D.; Svetına, A.; Turk, N. and Flegar-Meštrić, Z. (2008): Influence of oxidative stress and metabolic adaptation on PON1 activity and MDA level in transition dairy cows. Anim Reprod Sci,108, 98-106.

Turk, R. (2009): The role of HDL-associated enzymes in bovine reproduction. In: HDL and LDL Cholesterol: Physiology and Clinical Significance. (Pagano, S. I., B. N. Strait, Eds.), NY, USA; Nova Science Publishers: pp. 129-145.

Turk, R.; Podpečan, O.; Mrkun, J.; Kosec, M.; Flegar-Meštrić, Z.; Perkov, S.; Starič, J.; Robić, M.; Belıć, M. and Zrımšek, P. (2013):
Lipid mobilisation and oxidative stressas metabolic adaptation processes in dairy heifers during transition period. Anim Repro. Sci, 141, 109-115.

Temizel, E.M.; Senturk, S. and Kasap, S. (2009): Clinical, haematological and biochemical findings in Saanen goat kids with naturally occurring heat stroke. Tierärztl Prax, 37, 236-241

Vanholder, T.; Leroy, J.; Dewulf, J.; Duchateau, L.; Coryn, M.; De Krulf, A. and Opsomer, G. (2005): Hormonal and metabolic profiles of high yielding dairy cows prior to ovarian cyst formation on first ovulation postpartum. Repr Dom Anim, 40, 460-467.

Vazquez-Annon, M.; Bertics, S.; Luck, M.; Grummer, R.R. and Pinheiro, J. (1994): Peripartum liver triglyceride and plasma metabolites in dairy cows. J Dairy Sci, 77, 1521-1528.

Watson, T.D.G.; Burns, L.; Packard, C.J. and Shepherd, J. (1993): Effects of pregnancy and lactation on plasma lipid and lipoprotein concentrations, lipoprotein composition and post-heparin lipase activities in Shetland pony mares. J Reprod Fertil, 97, 563-568. 
